\title{
Problems and Prospect of Organic Farming in Developing Countries
}

\author{
Bello. W. B*
}

\begin{abstract}
Agricultural development strategy for developing countries need to be geared towards increasing the productivity of land under cultivation, with reduced cost, higher efficiency use of inputs with little or no harm to both human and the environment. The prime requisite is the promotion of a healthy soil-plant-environment system to reduce Land degradation and abuse of the inputs. A new strategy of promoting eco-friendly farming is through the modification of the present systems of farming in the area of soil nutrient restoration to encourage the use of organic materials, termed organic farming. This paper discusses the problems and prospects of adopting this system in developing countries.
\end{abstract}

\section{Introduction}

Human survival demands that environmental considerations should underpin all aspects of development, whether physical or social and must not threaten the integrity of the environment. Sustainable agricultural system must address issues of environmental, economic and social sustainability in its approach apart from inputs or tools consideration. Hence, the needs to adopt production systems that are environmentally friendly especially in food production, this is the bases for Organic farming strategy.

Organic production systems are based on specific and precise standards of production, which aim at achieving agroecosystems, which are economically, socially and ecologically sustainable. According to Regnold, (2001); Organic farming aims at improving soil fertility by providing an ideal soil system for plant growth. It improves the physical, chemical and biological properties of the soil and thus, builds up the soil health.

The relationship between soil organic matter and crop productivity have been cited in literatures, (Agboola and Omueti,1982) ; was of the view that crop response to applied fertilizer depends on soil organic matter availability. Hue (1992); opined that among the problems inherent to tropical soils are; soil acidity, excessive aluminum, deficient calcium, and low organic matter. (Cook and Ellies; 1987) also viewed that organic matter additions are the only means of making some soils economically productive. Therefore, the use of organic amendments is synonymous to soil productivity (Reichard et al; 2000).

Increasing soil organic matter has added benefit of improving soil quality and thereby enhancing the long -term sustainability of agriculture (Laird, 2001). The above findings, led to the call for organic farming which mainly relies on the principle of organic matter generations.

This paper therefore, discusses the problems and prospects of Organic farming in the developing countries as an approach for improving the Nutrient use efficiencies and sustainability of agricultural productivity. It is arranged into sections; following the introduction is the origin and development of organic farming; then the concept and principles; sources of organic manure; the prospect of organic farming; the problems of organic farming in developing countries and finally the conclusion.

Origin and development of organic Farming

Organic farming systems has its roots in alternative farming systems, and these systems have existed for years in various countries of the world, questioning whether intensive agriculture, which uses artificial fertilizers and sprays to provide

\footnotetext{
*Department of Dry-land Crop and Horticultural Sciences, Faculty of Dry-land Agriculture and Natural Resources, Mekelle University, Ethiopia. waswarith@yahoo.com
} 
the maximum yield, is the best way to produce foods that promote human health. Further more, agreeing that the impact of the production method on the surrounding environment should be included as a parameter of quality. Organic farming therefore, emerges as the outcome of theory and practice of the early years of the $20^{\text {th }}$ century but its recognition is recent. There have been three important movements:

Biodynamic agriculture, which appeared in Germany under the inspiration of Rudolf Steiner [1920]. Organic farming , originated in England from the theories developed by Albert Howard in his Agricultural Testament in 1940 following the work of Rodale in late 1930s in United States but this idea was known has the use of organic manure in Africa and most developing world generally.Biological agriculture which started in Switzerland by Hans-Peter Rush and Hans Muller. [1930s] .

However, the inception of the concepts is in -line with Traditional farming came into focus in the early 70's when concerted effort began on soil characteristics. Agboola, (1970) concluded that soil organic matter is significantly correlated with cat ion exchange capacity , and all available nutrients especially $\mathrm{N}, \mathrm{P}, \mathrm{K}, \mathrm{Mg}, \mathrm{S}, \mathrm{Zn}$, and $\mathrm{Cu}$ in soils of South-Western Nigeria. Charreau (1994) then described organic carbon as a life wire of soils in the tropics, particularly in the dry-land region of Africa and marks the stage back into organics.

Despite all the differences of emphasis mentioned above, the common features of all these movements, which are the source of some of the terms protected by community rules, is to stress the essential link between farming and nature, and to promote respect for natural equilibrium. The principle is in line with Agboola (1970)'s idea, who had advocated for better farming systems which will employ a combination of fertility building practices appropriate to the local conditions for crop production in south west Nigeria. The movements distance themselves from the interventionist approach to farming, which maximizes yields through the use of various kinds of Synthetic products.

By the end of the 1970s, organic farming came to the forefront in response to the emerging awareness of environmental conservation issues. New associations grow up, involving producers, consumers and others interested in ecology and lifestyle more tune with nature. These organizations draw up their own specifications, with rules governing production methods.

It was in the 1980's that Organic farming really took off, when the production method continued to develop, along with consumers' interest in its products, in almost all part of the world. The situation conducive to the development of organic farming was mainly due to consumers' acceptance and its environment-friendly products. At the same time, the public were gradually recognizing organic farming, focusing it as research topics and adopting specific legislation (e.g. in Australia, France, and Demark).

\section{Concept and Principles of Organic farming}

The concept of organic farming is based on a holistic view point. Nature is more than just the separate individual elements into which it can be split. Principles and ideas of farming are found in the science of ecology, the interrelationship of living organisms and their environments. Organic farming largely excludes synthetic inputspesticides, herbicides and fertilizers- and focuses on sufficient biological processes such as composting and other measures to maintaining soil fertility, natural pest control, diversifying crops and livestock. Organic agriculture gives priority to long term ecological health, such as biodiversity and soil quality, contrasting with conventional farming, which concentrates on short term profit gains (Trewavas, 2001). Hence, Organic agriculture was defined by National Organic standards Board of the USA (1996) as "an ecological production management system that promote and enhance biodiversity, biological activity. It is based on minimal use of off- farm inputs and on management practices that restore, 
maintain and enhance ecological harmony". Tomas (2003), also explained that the organic associations in Scandinavia have agreed on the following definition of organic farming:

Organic farming means a selfsufficient and sustainable agroenvironmental system in equilibrium. The system is based on local and renewable resources. Organic farming builds on an integrated ethos, which encompasses the environmental, economic and social aspects in agricultural production both from a local and global perspective. Thus organic farming perceives nature as an entity, which has value in its own rights; human- beings have a moral responsibility to steer the course of agriculture so that the cultivated landscape makes a positive contribution to the countryside.

Codex (1999), viewed organic farming as holistic production management systems (for crops and livestock) emphasizing the use of management practices in preference to the use of off-farm inputs. This is accomplished by using, cultural, biological and mechanical methods in preference to synthetic materials.

However, in the context of this paper, organic agriculture is agricultural production without the use of synthetic chemicals (fertilizers, pesticides, antibiotics, e.t.c.). For crop production, organic materials such as compost and manure are used to maintain soil organic matter and as sources of nutrients. Nitrogen-fixing as well as pest resistant plant varieties are utilized. Further, the incorporation of soil management techniques such as mulching, intercropping and crop rotation are integral components of an organic farming system. Another important characteristic of an organic farming system is the use of agroforestry system.

An organic production system is designed to work constructively with natural biological cycles and to operate with minimal external inputs. In order to ensure that the organic system is efficient and sustainable in the long term, sustainable crop rotations, nutrient recycling, encouragement of a rich biodiversity and other management practices are necessary prerequisites.

According to Codex (1999), an organic production system have the following objectives: increase soil biological activity; maintain long-term soil fertility; recycle waste of plant and animal origin in order to return nutrients to the land; minimize the use of non-renewable resources; rely on renewable resources in locally organized agricultural systems; promote the healthy use of soil, water and air, as well as minimize all forms of pollution that may result from agricultural practices; handle agricultural products with emphasis on careful processing methods in order to maintain the organic integrity and vital qualities of the product at all stages; established an existing farm through a period of conversion; the appropriate length of which is determined by site-specific factors such as the history of the land, and type of crops and livestock to be produced.

Organic farming is also about animal welfare, and the regulations governing organic farming contain detailed guidelines as to how specific livestock should be bred and fed. Organic livestock farming is however, based on the principle of a close link between animals and the soil. The need for a link with the soil requires animals to have free access to outside areas for exercise, and also implies that their feed should not only organic, but needs to be made on the farm. This sector of organic farming is, more or-less, strictly regulated by provisions on animal welfare and veterinary care.

A common feature of all organic objectives is that farming people are considered to be part of nature- in a rotation. Moreover, nature is so complex that we do not have a full understanding of the consequences of our actions on ithence, there is need to be careful when working on it. Organic farming is also take cognizance of the cultural and social aspects of agriculture, (Tomas, 2003).

\section{Sources of Organic Manure}

The fertility and biological activity of the soil must be maintained or increased by the cultivation of legumes, green manure or deep-rooting plants in a multi-annual rotation program 
(EEC;1991). By- products from organic livestock farming may also be used within the limits set out. The main sources of organic manure has been identified to include the following:

\section{(a) The use of compost;}

Compost is a well- or partially decomposed, humidified organic material with a total carbon concentration to total Nitrogen concentration ratio $(\mathrm{C}: \mathrm{N})$ of about 10. Most compost carbon is contained in microbial biomass and in well-decomposed organic matter that is resistant to further degradation. The Nitrogen mineralization rate of composts made from feed stocks high in cellulose and lignin tends to be slower than those containing less "woody" constituents even when the $\mathrm{C}: \mathrm{N}$ ratios are similar.

Among the practices recommended for improvement of the soil quality and fertility in tropical regions is the application of composted organic wastes, which slowly release significant amounts of nitrogen and phosphorus (Eighball, 2001).The regular use of composted material is a prerequisite for sustained soils with inherent low natural fertility (Schoningh and Wichmann, 1990). As reported by Nyamangara et al.; (2003), management of soil organic matter with the use of composted organic waste is the key for sustainable agriculture. The use of composted organic waste as fertilizer and soil amendment not only results in an economic benefit to the small- scale farmer but it also reduces pollution due to reduced nutrient run-off, and $\mathrm{N}$ leaching (Nyamangara, 2003).

(b) The use of green manure and crop residue.

Organic growers are increasingly utilizing legume cover crops as green manures in rotations to meet Nitrogen needs of crops. Cover crop Nitrogen accumulation and total biomass depend on the length of growing season, local climate and soil conditions.

However, it has been reported by Beltran et al.; (2002) that green manures when composted increased soil organic matter (SOM), provides nutrients for plant growth, alleviate aluminum toxicity, and render phosphorus more available to crops. Cover crops and other plant material when left or ploughed into the soil enhance and protect soil quality. Dabney et al.[2004]; also noted that soil tillage following residue removal increased soil loss between 26-47\%, while Reicosky et al.; (1995) also reported a strong relationship between residue amount and organic matter in the soil top $15 \mathrm{~mm}$.

(c). Poultry manure as a Fertilizer

The concentration of animal production systems has increased efficiency and improved overall economic return for animal producers. Manure, once valued as a waste by farmers, is now treated as a resource for the sustainability of the soil. Poultry, Swine and Cattle manure has long been recognized as the most desirable of all natural animal fertilizers because of the high nitrogen content. The estimates of the fraction of organic $\mathrm{N}$ that is mineralizable (fm) in some manure indicated a range from 0.08 to 0.52 for swine, 0 to 0.51 for cattle, and $0.17-0.0 .73$ for poultry litter (Cabrera and Gordillo, 1995). The mineralizable nitrogen in poultry litter has also been found to be strongly related to total nitrogen and uric acid concentration (Gordillo and Cabrera, 1997). Some work also indicated high nitrogen manure arising from poultry and swine, to suppress diseases by generating high ammonia and/ or nitrous acid concentration in the soil (Lazarovits, 2001).

The primary way of reducing the risks associated with land application of these animal manures is by addressing the application rate, timing, and location during utilization. Poultry litters that are applied to fallow soil has being found to cause substantial decrease in run off and soil loss (Giddens and Barnett, 1980) while Mueller et al. ; 1984 also reported, the addition of diary manure to corn plots to reduce soil loss. The soil nematodes which serves as both plant parasites and contributors to the re- mobilization of nutrients has being reported by Griffiths et al.; (1994) to decrease in number with the use of poultry manure but with no effects from the addition of cattle manure on farm. 


\section{Prospect of Organic Farming}

\section{A. Consumer Acceptance:}

Consumers are now turning to organic food because they believe it to be tastier, as well as healthier, both for themselves and environment. Alfoldi et al.[1998]; summarized the published literature on differences between organic and other management systems and found out that, of the seven studies comparing taste of crop produced with organic management versus conventional management, they judged that there was positive impact of organic management in two apples in Australia (Velimirou et al.; 1995), and potatoes in Finland (Varies et al.; 1996). Nevertheless, the other five studies show no differences.

Despite the higher cost for Organic products, consumers are willing to pay for their preference. Economically, organic fruit growing is comparatively healthy, but depends on a higher farm gate price for product (Weibel et al.; 2004). Another reason for Organic products prominence is the opposition to genetically modified food.

\section{B. Environmental Friendly. \\ Pest- control}

Organic

farming

is

environmentally friendly. This is because it is well known that chemicals have destroyed many beneficial insect species and have caused environmental degradation. For instance, Korean researchers had reported that avoiding pesticides in paddy fields encourages the muddy loach fish, which effectively control mosquitoes that spread malaria and Japanese encephalitis (John Bonner, 2002).

The ever-increasing threat to ground water pollution from inefficient and indiscriminate use of fertilizers and pesticides respectively, demand much concern. These threats are eliminated in organic farming systems since natural pest control is practiced. It is confirmed in California that Organic tomato production without synthetic insecticides does not lead to increased crop losses as a result of pest damage (Letourneau and Goldstein, 2001). In-fact, Organic farmers' primary strategy in controlling pests and diseases is with the use of prevention method.

\section{Higher biodiversity}

Organic farming also provides energy for microbial activity and this has been suggested as an indicator of change for soil properties (Agren and Bosta, 1998) because the size and activity of the microbial quotient is directly related to the amount and quality of carbon available (Breland and Eltun, 1999). Therefore, increase in microbial quotient. Organic farms, often explores biodiversity than conventional farms because it is usually with more trees, a wider diversity of crops and many different natural predators, which control pests and help prevent disease. (Parrott and Marsden, 2002).

\section{Better Soils.}

Increasing soil organic matter by organic farming has the added benefit of improving soil quality and thereby enhancing the long-term sustainability of agriculture (Laird et al.; 2001). Organic agriculture also help to conserve and improve precious resource-the topsoil, compaction, nutrient loss and erosion, organic farmers use trees, shrubs, leguminous plants to stabilize and feed soil, dung and compost to provide nutrients, and terracing which prevent erosion and conserve ground water (Parrot and Marsden,2002).

Problems of Organic farming Production in Developing Countries

Developing countries are already producing a wide range of Organic products and many are thriving well. However, most of them are often faced by a number of constraints, such as lack of technical know-how, for example organic farming practices and production methods, and lack of market information, for example which products to grow, which markets and distribution channels to choose, competition, market access, e.t.c. with producers in developed countries, is that of certification, which posses not only a technical problem but adds considerable costs to the product, which have to be borne by the consumer in one way or another. Nevertheless, importers, food manufacturers, retail organizations and consumers need a guarantee of Organic origin.

Another impediment is that, Organic products are expensive presently. 
The reason why prices are higher for organic foods, reflect many of the costs as conventional foods in term of growing, harvesting, transportation and storage. Organically produced foods must meet strict regulations (certification), and intensive management and this why the farming is mostly done on a smaller scale. Organic farming is still faced with the problem of higher labour input in its operation. This is why Pandel and Lampkin (1994), stated that the labor input measured in terms of either hours of work or full -time job is usually greater on organic than on equivalent conventional farms. Other studies shows that the main reason why organic farming require more labor is to carry out manual and mechanical tasks essential to growing. The preparation for sale on the farm or on the market also involves more labour on organic holdings (Patrick and Alain, 1999).

In-addition, Organic farming is still hampered by lack of clarity: Consumers were not always sure about what was really covered by organic farming, and the restrictions it implied. The reasons for the confusion lay, among other things, in the existence of a number of different "schools" or philosophies, the lack of harmonized terminology, the nonstandard presentation of products and the tendency to blur the distinctions between concepts such as organic, natural, whole some and so on. The situation was worsened by cases of fraudulent use of labeling referring to organic methods.

Despite all the above mentioned constraints, remarkable results of Organic farming have come from small farmers in developing countries. For example, in Brazil the use of green manures and cover crops increase maize yields by between $20 \%$ and 250\%; in Tigray, Ethiopia, yields of crops from composted plots were 35times higher than those treated only with chemicals; yield increases of $175 \%$ have been reported from farms in Nepal adopting agro-ecological practices; and in Peru the restoration of traditional Incan terracing has led to increases of $150 \%$ for a range of upland crops.

Projects in Senegal involving 2000 farmers promoted stall-fed livestock, composting systems, use of green manures, water harvesting systems and rock phosphate, increased the yields of millet and peanuts by $75-195 \%$ and $75-$ $165 \%$ respectively. This is because the soils have greater water retaining capacity, fluctuation in yields is less pronounced between high and low rainfall years. Another project in Honduras, emphasized soil conservation practices and Organic fertilizers, saw a tripling or quadrupling of yields. All these, confirms the sustainability and environmental friendly nature of Organic farming in developing world (Parrot and Marsden,2002).

\section{Conclusions}

For several years, conventional agriculture has been increasingly subject to strict environmental and animal welfare rules. This has meant the development of new approaches and methodologies, such as Integrated agriculture (Ojeniyi, 2000; ).The organic farming sector needs to see where it stands in relation to these new developments, and to consider the production rules it applies with a view to maintaining a specific identity clearly distinguished from conventional agriculture.

Comparisons between conventional and organic farming are actually not on a level playing field because input into organics is small compared to the former. Organic research tends to be more diffuse, farm-base participatory, drawing on local knowledge and tradition. It also focuses on public goods, resources and tools that are not readily patentable. This explains why organic farming attracts little investment from private sources compare to conventional and biotechnological approaches (Parrot and Marsden, 2002).

Research in Organic farming has increased considerably in the developing countries recently, but there is still a need for targeted research activities to help promote and develop organic farming. Many of the concerns of sustainability today is focus on environment and nature, animal welfare, product quality and health are all fundamental aspect of organic farming. 
Therefore, there is need for research support to develop feasible and sustainable Organic agricultural techniques, which are site specific. It is important for the governments in developing countries and International NGOs to fund research that will capacitate to monitor and re-evaluate the production

\section{References}

Agboola , A.A. Omueti J.A.; (1982). Soil fertility problem and its management in Tropical Africa. Paper presented at the International Institute of Tropical Agriculture. Ibadan, Nigeria pp25

Agren, G.I. and Bosatta, E. (1998). Theoretical Ecosystem Ecologyunderstanding Element Cycles. Cambridge University press, Cambridge.

Alfoldi, T.; Bickel, R.; and Weibl, F.; (1998) Vergleichande Qualitatsachungen Zwischen biologisch und konventioneli angebauten production: Ein Kritsche Betrachtung der forchungserbeiten Zwischa 1993 un 1998.; p.31 Coop Schweiz, frick, Switzerland

Beltran, E.M.; Miralles de Imperial, ; Porcel,M.A.; Delgado, M.M.; Beringola, M.L. ; Martin, and M. Bigerigo. (2002). Effects of sewage Sludge compost application on ammonium nitrogen and nitrate-nitrogen content on Olive Grove soils. Proceedings; $12^{\text {th }}$ International soil conservation organization Conference. May 26-31, Beijing China.

Breland, T.A.; R.; (1999). Soil microbial biomass and mineralization of carbon and nitrogen in ecological, Integrated and conventional forage and arable cropping.Systems. Biology and fertility of soils, 30, pp193-201.

Charreau. C. (1994). Organic matter and biochemical properties of Soils in the dry tropical Zone of West Africa. FAO soils Bull. 27: 313-341, Rome, Italy.

Cabrera, M.L. and Gordillo, B. ; (1995). Nitrogen release from land -applied animal Manures. In K.steele (eds). Animal waste and the Land-Water interface, CRC Press, New York.

Codex Alimentarius, (1999). Guidelines for the production, processing, labeling and Marketing of Organic Produced foods, Commission, CAL/GL 32. systems in organic farming. The research support activities should also be concerned with the identification of suitable varieties of crops that are adapted to organic farming and supply nurseries with appropriate germplasm and organic seeds in the production areas.

Cook, R.L. ;and Ellis B.G. ; (1987). Soil Management: A world view of conservation and production. John Wiley \& sons. New York. Singapore. Pp152-170. Dabney, S.M.; Wilson, G.V.; Mcgregor, K.C.; and Foster G.R.; (2004). History, residue and tillage effect on erosion of loessial soil. Transactions of the American Society of Agricultural Engineer. Pp740775.

European Economic Commission (EEC), (1999).Article 1 of council regulation No22092/91 of24june 1991 on Organic production of agricultural products and food stuffs (0) L98, 22.7.1991, page1.

Egball and Bahman (2001). Composting manure and organic residue. Cooperative Extension publication (Nebguide), Institute of Agriculture and Natural Resources, University of Nebraska, Linkoln.

Gale, W.J.; and Cambardella, C.A.; (2000). Carbon dynamics of surface residue- and root derived matter under simulated no-till. Soil science society of America Journal 64(1): 190-195.

Giddens, J.; and Barnett A.P.; (1980). Soil loss and microbiological quality of run off from treated with poultry litter. Journal of Environmental Quality. 9(3): 518-520.

Hue, N.V.(1992). Increasing soil productivity for the humid Tropics through Organic matter Management. Tropical and Sub tropical Agricultural research, progress and Achievements. The pacific Basin Administrative Group. Livestock waste Management, vol. I .; by M.R. Overcash, CRC press, Boca Raton, FLa.

John Burner, (2002). Organic rice is as twice nice. Report from the International Congress of Ecology, 1. 
Laird, D.A. Martens, and Kingery W.L. ; (2001). Nature of clay-Humic complexes in an Agricultural soil: I. Chemical, Biological, and Spectroscopic Analysis. Soil science society of America Journal,65:pp1413-1418.

Lazarovite, G.; (2001). Management of soil pathogens with organic soil amendments. A disease control strategy savaged from the past. Can. J. Plant path. 23:1-7.

Letourneau, D.K.; and Goldstein B. (2001). Pest damage and arthropods community structure in Organic conventional tomato production in California; J. Applied Ecology 38(3): 557-570

Linden, D.R.; Clapp, C.E. and Dowdy, R.I.; (2000). Long -term corn grain and Stover yields as with the act of tillage and residue removal in East Central Minnesota.Soil and tillage research 56:101-140.

Nyamangara, J.; Bergstrom, L.F.; Piha ,M.I.; and Giller, K.E.; (2003). Fertilizer useEfficiency and Nitrate leaching in a Tropical sandy soil. Journal Environmental Quality 32:599-606.

Ojeniyi, S.O.; (2000). Effects of goat manure on soil nutrients and Okra yield in a rainforest area of Nigeria. Applied Tropical Agriculture 5:20-23.

Pandel S.; and Lampkin N.; (1994). Farm level performance of organic farming systems, in Lampkin, N.; Pandel, S.; (eds). The economics of Organic farming: an international review.'

Parrot, N. and Marsden, T.; (2002). The real Green Revolution: Organic and Agroecological farming in the London: Green peace Environment Trust. Pp1-6.

Waaigford.Patrik H. and Alain J.; (1999). Organic farming (Eurostat). Pp20-30

Reganold, J.P.; Glover J.D.; Andrews P.K.; and Hinman J.R.; (2001). Sustainability of three apple production Nature 410(19April2001):926-930.

Reichardt, w.; Inubushi, K.; Tidje, J.; (2000).Microbial processes in $\mathrm{C}$ and $\mathrm{N}$ dynamics In :Kirk, G.J.D.; OIK,D.C. (Eds). Carbon and Nitrogen Dynamics in flooded soils International Rice Research Institute, Makati city, Philippines, pp101-146.

Reiscosky, D.C.;Kemper, W.D.; Langdale, G.W.; Douglas , C.L.; and Rasmussen,P.E.; (1995). Organic matter changes resulting from tillage and biomass production, Journal of soil and Water conservation May -June pp253261.

Schoningh, E.; and Wickmann, W.; (1990). Organic manures meeting expectations? Proceedings, FAO fertilizers Conferences. April 1990. Rome . Development and Consultation organization.

Trewavas A.; (2001). Urban myths of Organic farming: Organic agriculture began as an ideology, but carry today's needs? Nature 410 (22march 2001):409-410.

Tomas Fibiger, (2003). Organic farming in Demark. Ministry of food, Agriculture and fisheries.Home page of Denish Agricultural Advisory service pp1-8.

Varis, E.; Pietila, L.; and kolkkalaiknen, K.; (1996).Comparison of Conventional, Integrated and Organic potato production in field experiments in Finland. ActaAgriculture Scandinavia. Section B, Soil and Plant science, 46(1), 41-48.

Velimirov, A.; Plochberger, K.; Schott, W.; and Walz, V. (1995). Neue UtersuchungenZur Qualitat Unter schiedlich angebauter ApfelNilchtalles, was golden ist, $1^{\text {st }}$ auch delicious! Das Bio skop. Faschzeitchrift fur Bioland bau und okologie, 6, 4-8. 